\title{
Hubungan Asupan Makan, Status Gizi, Dan Usia Menarche Ibu Dengan Menarche Dini Pada Remaja Putri Di Wilayah Perumahan Bumi Pertiwi 2, Kabupaten Bogor
}

\section{The Relationship Of Dietary Intake, Nutritional Status, And Maternal Age Of Menarche With Early Menarche In Adolescents In The Perumahan Bumi Pertiwi 2, Bogor.}

\author{
Widya Siestianing Rachma*, Ikha Deviyanti Puspita* \\ *Program Studi Gizi Program Sarjana, Fakultas Ilmu Kesehatan, UPN "Veteran” Jakarta \\ (widya.s.rachma@gmail.com)
}

\begin{abstract}
ABSTRAK
Telah terjadi penurunan usia menarche dalam beberapa kurun waktu terakhir. Berbagai macam penyakit degeneratif dapat muncul akibat terjadinya menarche dini, wanita dengan menarche dini memiliki risiko relatif lebih tinggi terhadap terjadinya penyakit jantung, kanker payudara, dan meningkatkan 2.3 kali resiko sindroma metabolik terlepas dari berbagai etnik dan ras. Penyebab terjadinya menarche dini dapat disebabkan oleh faktor genetik atau perubahan faktor lingkungan, status menarche ibu (genetik), status gizi, gaya hidup. Tujuan penelitian ini untuk mengetahui Hubungan Asupan Makan, Status Gizi, Dan Usia Menarche Ibu Dengan Menarche Dini Pada Remaja Putri Di Wilayah Perumahan Bumi Pertiwi 2, Kabupaten Bogor. Penelitian ini menggunakan desain cross sectional dengan subjek penelitian yaitu remaja putri yang berusia 10-14 tahun di wilayah Perumahan Bumi Pertiwi 2 sebanyak 40 orang. Variabel yang diteliti pada penelitian ini adalah asupan makan, status gizi, dan usia menarche ibu. Hasil dari penelitian ini adalah terdapat hubungan antara asupan protein serta status gizi dengan usia menarche, sedangkan pada asupan energi, lemak, karbohidrat, kalsium ,serta usia menarche ibu tidak memiliki hubungan dengan usia menarche remaja putri di wilayah Perumahan Bumi Pertiwi 2.
\end{abstract}

Kata Kunci : Menarche, Asupan Makan, Status Gizi, Usia Menarche Ibu

\begin{abstract}
There has been a decrease in the age of menarche in the last few years. Various degenerative diseases can appear due to early menarche, women with early menarche have a relatively higher risk of heart disease, breast cancer, and increase 2.3 times the risk of metabolic syndrome regardless of ethnicity and race. Early menarche can be caused by genetic factors or changes in environmental factors, maternal age of menarche (genetic), nutritional status, and lifestyle. The purpose of this research is to find out the relationship of dietary intake, nutritional status, and maternal age of menarche with early menarche in adolescents in the Perumahan Bumi Pertiwi 2, Bogor. This study uses a cross sectional design with research subjects is adolescents with aged 10-14 years and life in the Perumahan Bumi Pertiwi 2 as many as 40 people. The variables studied in this study were food intake, nutritional status, and age of maternal menarche. The results of this study are there is a relationship between protein intake and nutritional status with the age of menarche, while the energy intake, fat, carbohydrates, calcium, and the age of maternal menarche have no relationship with the age of menarche in adolescents in the Bumi Pertiwi 2
\end{abstract}

Keyword : Menarche, Dietary Intake, Nutritional Status, And Maternal Age Of Menarche 


\section{PENDAHULUAN}

Menarche merupakan salah suatu kejadian yang penting bagi kehidupan reproduksi wanita, karena pada saat itu wanita akan mengalami menstruasi pertamanya (Jahanfar \& Walters, 2019). Menurut beberapa penelitian terdahulu telah terjadi penurunan usia menarche dalam beberapa kurun waktu terakhir, Dalam periode 2006-2010 usia rata-rata menarche adalah 13,61 tahun, diketahui 37,5\% remaja putri di Indonesia akan mengalami menarche pada usia 13 hingga 14 tahun (RISKESDAS, 2010), dan pada penelitian Ganabathy et al., 2016 yang dilakukan di daerah Jatinangor, Jawa Barat diketahui bahwa generasi saat ini (usia menarche tahun 20042013) memiliki usia rata-rata menarche 12,28 tahun.

Dalam penelitian $\mathrm{Yu}$ et al (2020) mengungkapkan bahwa menarche dini dapat menyebabkan gangguan stress, kehamilan, memburuknya kesehatan seseorang, hingga meningkatnya kejadian sindrom metabolik (Chang CJ, Lai MM dalam Fathin et al., 2017).

Ketika seorang remaja putri mengalami menarche pada usia dibawah 12 tahun, maka dengan demikian dapat dikatakan sebagai menarche dini, menarche dini dapat terjadi pada perempuan yang berusia 9 hingga 11 tahun dengan kejadian menarche yang lebih banyak terjadi pada perempuan yang berusia 10 tahun (Sari et al., 2016).

Penyebab terjadinya menarche dini menurut Ganabathy et al., 2016 disebabkan oleh faktor genetik atau perubahan faktor lingkungan, berikut adalah beberapa faktor yang berpengaruh terhadap terjadinya menarche dini seperti usia menarche ibu, gaya hidup serta indeks massa tubuh (Wulandari et al., 2015).
Menurut penelitian Rogers et al., (2010) diperoleh hubungan yang signifikan terkait asupan makan responden sebelum mengalami menarche dengan usia menarche mereka, asupan yang dikonsumsi memiliki komposisi seperti protein, lemak dan karbohidrat juga memiliki peran pada asupan setiap orang.

Perempuan yang status gizinya lebih besar akan mendapatkan kematangan seksualnya menjadi lebih dini. Hal tersebut dikarenakan ketika seseorang memiliki IMT yang lebih besar maka akan mempengaruhi paparan dari hormon estrogen serta progesteron yang kadarnya meningkat, hal tersebut dapat berdampak pada kejadian menarche (Derina, Karis Amalia dalam Putra, Pradnyani, et al., 2016).

Kecepatan pada pertumbuhan serta perkembangan pada tubuh anak dipengaruhi oleh usia menarche pada ibu, sehingga dengan demikian hal tersebut dapat mempengaruhi waktu terjadinya menarche, kejadian itu di perkirakan lokus yang bekerja dalam mengatur hormon estrogen telah diturunkan pada anaknya (Derina, Karis Amalia dalam Putra, Pradnyani, et al., 2016).

\section{METODE PENELITIAN}

Penelitian ini termasuk jenis penelitian analitik observasional dengan menggunakan studi kuantitatif dengan desain studi cross sectional. Pada penelitian ini yang digunakan adalah data primer untuk mengetahui hubungan antara variabel independen dengan variabel dependen. Dalam penelitian ini pengambilan sampel menggunakan teknik purposive sampling. Kriteria inklusi penelitian ini adalah Remaja yang berusia 10-14 tahun diwilayah Perumahan Bumi Pertiwi 2 dan bersedia menjadi responden, 
lalu kriteria ekslusi yaitu remaja yang sedang sakit.

Data yang digunakan dalam penelitian ini merupakan data primer meliputi data responden yaitu nama, kelas, tanggal lahir, usia menarche, lalu data antopometri terkait berat badan dan tinggi badan, kemudian data asupan makan dan data usia menarche ibu. Kemudian dilakukan analisis univariat untuk mengetahui gambaran pada variabel penelitian, kemudian dilakukan analisis bivariat untuk mengetahui hubungan asupan makan, status gizi, dan usia menarche ibu dengan menarche dini dengan menggunakan uji korelasi Pearson.

\section{HASIL}

Tabel 1. Frekuensi Gambaran Usia Menarche

\begin{tabular}{lll}
\hline Variabel & n & \% \\
\hline Kategori Status & & \\
Menarche & & \\
Dini & 21 & 52.5 \\
Normal & 19 & 47.5 \\
\hline
\end{tabular}

Sumber: Data Primer

Dapat dilihat pada tabel 1 bahwa terdapat lebih banyak responden yang mengalami menarche dini $(52.5 \%)$. Usia menarche termuda yaitu berusia 10 tahun, sedangkan yang paling lama adalah 14 tahun.

Dengan rata-rata usia menarche yaitu 11.7 tahun, usia tersebut masih tergolong menarche dini. Hal tersebut dapat terjadi akibat beberapa macam hal, seperti kebiasaan makan responden di wilayah perumahan yang mengonsumsi makanan yang beraneka ragamseperti junk food hingga fast food yang mudah sekali untuk didapatkan, lalu pengaruh status gizi yaitu status gizi yang baik atau lebih, hingga lingkunganseperti yang diketahui hampir setiap responden memiliki handphone sehingga akan lebih mudah untuk mengakses video, gambar, berita, dan lainnya yang memungkinkan hal tersebut dapat terjadi karena minimnya pengontrolan dari orang tua.

Tabel 2. Frekuensi Gambaran Asupan Energi

\begin{tabular}{lcc}
\hline Variabel & n & \% \\
\hline Kategori & & \\
Asupan Energi & & \\
Lebih & 24 & 60.0 \\
Normal & 11 & 27.5 \\
Kurang & 5 & 12.5 \\
\hline
\end{tabular}

Sumber: Data Primer

Gambaran asupan energi pada penelitian ini menunjukkan bahwa dari total 40 responden, sebagian besar responden mengonsumsi energi berlebih yaitu sebanyak $60 \%$ responden. Ratarata asupan energi pada responden yang berusia 10-12 tahun yaitu 2441.8 kkal dan pada responden yang berusia 13-14 tahun rata-rata asupan energinya adalah $2342.7 \mathrm{kkal}$.

asupan energi pada responden berlebih hal tersebut dapat terjadi karena beberapa hal seperti pengaruh lingkungan, pergaulan, ekonomi terkait uang jajan yang diberikan media massa, hingga jenis makanan yang terdapat disekolah maupun di rumah dapat mempengaruhi konsumsi makanan pada anak.

Tabel 3. Frekuensi Gambaran Asupan Protein

\begin{tabular}{lcc}
\hline Variabel & n & \% \\
\hline Kategori & & \\
Asupan Protein & & \\
Lebih & 25 & 62.5 \\
Normal & 9 & 22.5 \\
Kurang & 6 & 15.0 \\
\hline
\end{tabular}

Sumber: Data Primer

Gambaran asupan protein pada responden menunjukkan sebagian besar mengonsumsi protein secara berlebih yaitu sebanyak $62.5 \%$. 
Rata-rata asupan protein pada responden yang berusia 10-12 tahun yaitu 72.9 gram dan rata-rata asupan pada remaja usia 13-14 tahun yaitu 69.2 gram.

Bahan makanan yang mengandung protein yang sering dikonsumsi oleh responden yaitu daging ayam, daging sapi, ikan, udang segar, dan telur ayam, lalu untuk protein nabati yaitu tahu serta tempe.

Tabel 4. Frekuensi Gambaran Asupan Lemak

\begin{tabular}{lcc}
\hline \multicolumn{1}{c}{ Variabel } & n & \% \\
\hline Kategori & & \\
Asupan Lemak & & \\
Lebih & 26 & 65 \\
Normal & 10 & 25 \\
Kurang & 4 & 10 \\
\hline
\end{tabular}

Sumber: Data Primer

Pada kategori asupan lemak pada responden diketahui sebagian responden mengonsumsi lemak secara berlebih yaitu sebanyak $65 \%$ responden. Rata-rata asupan makan responden yang berusia 10-12 tahun yaitu $91.9 \mathrm{gr}$, dan pada responden yang berusia 13-14 tahun yaitu 89.96 gr. Lemak yang dikonsumsi secara berlebih dapat terjadi karena banyak responden gemar mengonsumsi makanan junk food, jajanan atau makanan tinggi lemak, pengaruh dari media elektronik serta kurangnya makanan sehat yang tersedia dilingkungan sekolah atau dirumah.

Tabel 5. Frekuensi Gambaran Asupan Karbohidrat

\begin{tabular}{lcc}
\hline \multicolumn{1}{c}{ Variabel } & n & \% \\
\hline Kategori & & \\
Asupan & & \\
Karbohidrat & & \\
$\quad$ Lebih & 15 & 37.5 \\
$\quad$ Normal & 19 & 47.5 \\
$\quad$ Kurang & 6 & 15.0 \\
\hline
\end{tabular}

Sumber: Data Primer
Dapat dilihat sebagian besar responden mengonsumsi karbohidrat secara normal yaitu sebanyak $47.5 \%$, hal tersebut dapat terjadi karena responden mengonsumsi asupan karbohidratnya tidak berlebihan, dan sesuai dengan angka kecukupan gizi mereka. Rata-rata asupan karbohidrat pada responden yang berusia 10-12 tahun adalah 319.79 gr dan yang berusia 13-14 adalah 301.6 gr.

Tabel 6. Frekuensi Gambaran Asupan Kalsium

Variabel
$\begin{aligned} & \text { Kategori } \\ & \text { Asupan }\end{aligned}$
$\begin{aligned} & \text { Kalsium } \\ & \text { Kurang } \\ & \text { Cukup }\end{aligned}$
$\begin{aligned} & \text { Sumber: Data Primer } \\ & \text { Dapat dilihat bahwa sebagian besar }\end{aligned}$
responden dalam kategori kurang dalam
mengonsumsi kalsium hingga $82.5 \%$ responden
yang mengonsumsi kalsium secara kurang. Rata-
rata asupan kalsium pada responden yang berusia
10-12 perharinya adalah 589.15 mg serta pada
responden yang berusia 13-14 adalah 534.21 mg
dalam sehari. Hal tersebut dapat dikarenakan
karena kurangnya kebiasaan mengonsumsi
makanan yang mengandung kalsium pada
sebagian responden, harga yang cukup mahal,
kurangnya pengetahuan orang tua.

Tabel 7. Frekuensi Gambaran Usia Menarche

\begin{tabular}{ccc}
\hline Variabel & $\mathbf{n}$ & $\%$ \\
\hline $\begin{array}{c}\text { Kategori Usia } \\
\text { Menarche } \text { Ibu } \\
\text { Normal (12-14 } \\
\text { Tahun) }\end{array}$ & 38 & 95.0 \\
$\begin{array}{c}\text { Lambat (> } 14 \\
\text { Tahun) }\end{array}$ & 2 & 5.0 \\
\hline
\end{tabular}

Sumber: Data Primer 
Sebagian besar usia menarche pada ibu responden adalah normal yaitu sebanyak $95 \%$ ibu responden. Usia menarche termuda yaitu berusia 12 tahun, sedangkan yang paling lama adalah 17 tahun. Dengan rata-rata usia menarche yaitu 13 tahun. Hal tersebut dapat terjadi karena beberapa hal terkait saat ibu dari responden sebelum mengalami menarche seperti belum beragamnya makanan pada saat itu, makanan seperti junk food hingga paparan dari media tidak semudah saat ini, karena hand phone hingga internet tidak semudah sekarang untuk diakses.
Tabel 8 Frekuensi Gambaran Status Gizi

\begin{tabular}{ccc}
\hline Variabel & $\underline{\mathbf{n}}$ & \% \\
\hline $\begin{array}{l}\text { Kategori Status } \\
\text { Gizi }\end{array}$ & & \\
Lebih & 14 & 35.0 \\
Normal & 19 & 47.5 \\
Kurang & 7 & 17.5 \\
\hline
\end{tabular}

Sumber: Data Primer

Dapat dilihat bahwa sebagian responden memiliki status gizi normal yaitu sebanyak 47.5\%. Makanan yang dikonsumsi seseorang akan memberikan gizi yang optimal pada pada tubuh seseorang. Status gizi yang baik atau kandungan zat-zat gizi yang dipergunakan atau diserap secara efisien oleh tubuh memungkinkan pertumbuhan pada fisik, perkembangan pada otak, hingga kesehatan lebih bekerja lebih optimal (Almatsier dalam Nugroho et al., 2015).

Tabel 9. Hubungan Antara Asupan Makan Dengan Usia Menarche

\begin{tabular}{|c|c|c|c|c|c|c|c|}
\hline \multirow{3}{*}{$\begin{array}{l}\text { Kategori Asupan } \\
\text { Energi }\end{array}$} & \multicolumn{6}{|c|}{ Status Menarche } & \multirow{3}{*}{$p$-value } \\
\hline & \multicolumn{2}{|c|}{ Dini } & \multicolumn{2}{|c|}{ Normal } & \multicolumn{2}{|c|}{ Total } & \\
\hline & $\mathbf{n}$ & $\%$ & $\mathbf{n}$ & $\%$ & $\mathbf{n}$ & $\%$ & \\
\hline Lebih & 12 & 30 & 12 & 30 & 24 & 60.0 & \multirow{4}{*}{0.991} \\
\hline Normal & 7 & 17.5 & 4 & 10 & 11 & 27.5 & \\
\hline Kurang & 2 & 5 & 3 & 7.5 & 5 & 12.5 & \\
\hline Total & 21 & 52.5 & 19 & 47.5 & 40 & 100 & \\
\hline \multicolumn{8}{|l|}{ Protein } \\
\hline Lebih & 16 & 40 & 9 & 22.5 & 25 & 62.5 & \multirow{4}{*}{0.032} \\
\hline Normal & 4 & 10 & 5 & 12.5 & 9 & 22.5 & \\
\hline Kurang & 1 & 2.5 & 5 & 12.5 & 6 & 15.0 & \\
\hline Total & 21 & 52.5 & 19 & 47.5 & 40 & 100 & \\
\hline \multicolumn{8}{|l|}{ Lemak } \\
\hline Lebih & 15 & 37.5 & 11 & 27.5 & 26 & 65 & \multirow{4}{*}{0.505} \\
\hline Normal & 4 & 10 & 6 & 15 & 10 & 25 & \\
\hline Kurang & 2 & 5 & 2 & 5 & 4 & 10 & \\
\hline Total & 21 & 52.5 & 19 & 47.5 & 40 & 100 & \\
\hline \multicolumn{8}{|l|}{ Karbohidrat } \\
\hline Lebih & 9 & 22.5 & 6 & 15 & 15 & 37.5 & \multirow{4}{*}{0.139} \\
\hline Normal & 11 & 27.5 & 8 & 20 & 19 & 47.5 & \\
\hline Kurang & 1 & 2.5 & 5 & 12.5 & 6 & 15.0 & \\
\hline Total & 21 & 52.5 & 19 & 47.5 & 40 & 100 & \\
\hline \multicolumn{8}{|l|}{ Kalsium } \\
\hline Kurang & 17 & 42.5 & 16 & 40 & 33 & 82.5 & \multirow{3}{*}{0.119} \\
\hline Cukup & 4 & 10 & 3 & 7.5 & 7 & 17.5 & \\
\hline Total & 21 & 52.5 & 19 & 47.5 & 40 & 100 & \\
\hline
\end{tabular}




\section{PEMBAHASAN}

\section{Hubungan Antara Asupan Energi Dengan Usia Menarche}

Hasil uji statistik menunjukkan bahwa tidak terdapatnya hubungan yang signfikan antara asupan energi dengan usia menarche pada remaja putri yang berusia 10 sampai 14 tahun di wilayah Perumahan Bumi Pertiwi 2 ( $p$-value $=$ 0.991) dapat dilihat pada tabel 9. Hal tersebut dapat dikarenakan tingkat asupan energi tidak berdampak langsung pada dengan kejadian menarche, karena untuk dapat mempengaruhi kejadian menarche maka dibutuhkan asupan energi yang lebih banyak dan mempengaruhi berat badan, sehingga menciptakan lemak tubuh sebesar $17 \%$ yang diperoleh dari berat badan, serta masih terdapat faktor pendukung lain yang dapat mempengaruhi kejadian menarche seperti pengaruh stress, galingkunn, hingga hormone yang mempengaruhi menarche ( $\mathrm{LH}, \mathrm{GnRH}$, serta Estrogen) (Budi Mardiyanti., 2012) .

\section{Hubungan Antara Asupan Protein Dengan} Usia Menarche

Hasil uji statistik menunjukkan bahwa terdapatnya hubungan hubungan antara asupan protein dengan usia menarche pada remaja putri yang berusia 10 sampai 14 tahun di wilayah Perumahan Bumi Pertiwi $2(p$-value $=0.032)$ yang dapat dilihat pada tabel 9 .

Asupan protein yang berlebih dapat beresiko 3.2 kali lebih tinggi terkait kejadian menarche dini dibandingkan dengan seseorang yang mengonsumsi protein secara normal atau tidak lebih (Fathin et al., 2017). Mengonsumsi protein secara berlebihan dapat menyebabkan obesitas menjadi lebih beresiko, hal tersebut dapat terjadi akibat tubuh mensekresi insulin serta IGF-1. IGF-1 binding protein ditekan oleh hormon insulin yang disekresi didalam tubuh hal tersebut menyebabkan IGF-1 bebas ketersediaannya menjadi lebih banyak sehingga menstmulasi sekresi dari GnRH di hipotalamus (Karaolis-Danckert et al dalam Fathin et al., 2017). Sekresi GnRH yang berlebih dapat merangsang kelenjar pituari untuk mengeluarkan FSH serta LH menjadi lebih banyak. Ketika hormon seks jumlahnya lebih tinggi maka dapat mempercepat proses pematangan ovum serta proses ovulasi yang menyebabkan terjadinya menarche dini (Fathin et al., 2017).

\section{Hubungan Antara Asupan Lemak Dengan Usia Menarche.}

Hasil uji statistik menunjukkan bahwa tidak terdapat hubungan yang signifikan antara asupan lemak dengan usia menarche pada remaja putri usia 10-14 tahun di wilayah Perumahan Bumi Pertiwi 2. Hal tersebut dapat dilihat dari hasil $p$-value 0.505 yang mana $>0.05$ yang dapat dilihat pada tabel 9. Responden yang mengonsumsi lemak berlebih mencapai $65 \%$, yang diantaranya $37.5 \%$ mengalami menarche dini.

Konsumsi lemak yang berlebih tidak memiliki hubungan langsung terkait pengaturan pada hormon yang mengatur pertumbuhan somatik pada organ seksual. Ketika energi diperoleh dari makanan yang mengandung lemak maka akan membuat cadangan lemak yang terdapat didalam tubuh tidak menjadi berlebih, hal tersebut menyebabkan pelonjakan pada sekresi hormon leptin tidak terjadi (Hendri et al dalam Fathin et al., 2017). 


\section{Hubungan Antara Asupan Karbohidrat Dengan Usia Menarche}

Hasil uji statistik menunjukkan bahwa tidak terdapat hubungan yang signifikan antara asupan karbohidrat dengan usia menarche pada remaja putri usia 10-14 tahun di wilayah Perumahan Bumi Pertiwi 2, hal tersebut dapat dilihat dari hasil $p$-value 0.139 yang mana $>0.05$ pada tabel 9 .

Karbohidrat sendiri hanyalah sumber dari peningkatan asupan kalori selama fase luteal terhadap siklus menstruasi dan peningkatan ini menjadi lebih tinggi dibandingkan dengan fase folikuler (Path, dalam Nugroho et al., 2015). Asupan karbohidrat yang berlebih dapat mempengaruhi status gizi seseorang, responden dengan kondisi kekurangan atau defisit karbohidrat dapat mempunyai status gizi yang baik hal tersebut dikarenakan dalam menghasilkan energi karbohidrat akan dibantu oleh protein serta lemak, protein dan lemak juga dapat memiliki fungsi sebagai penghasil energi, sehingga ketika aktivitas responden sesuai dengan asupan energi maka masalah tidak akan terjadi terkait dengan status gizinya(Siwi \& Paskarini, 2018).

Hubungan Antara Asupan Kalsium Dengan Usia Menarche

Hasil uji statistik menunjukkan bahwa tidak terdapat hubungan yang signifikan antara asupan kalsium dengan usia menarche pada remaja putri usia 10-14 tahun di wilayah Perumahan Bumi Pertiwi 2, Kabupaten Bogor. Hal tersebut dapat dilihat dari hasil p-value 0.119 yang mana $>0.05$ pada tabel 9 .

Bahan makanan yang mengandung kalsium terutama produk susu beserta olahannya adalah asupan yang kompleks, dimana memiliki kandungan yang dapat mempercepat maupun memperlambat kejadian menarche, sehingga hal tersebut tidak mempengaruhi kejadian menarche (Carwile et al., dalam Chrisanti. 2018).

Tabel 10. Hubungan Antara Usia Menarche Ibu Dengan Usia Menarche Anak

\begin{tabular}{ccccccccc}
\hline $\begin{array}{c}\text { Kategori } \\
\begin{array}{c}\text { Menarch } \\
\text { eIbu }\end{array}\end{array}$ & \multicolumn{1}{c}{ Dini } & \multicolumn{1}{c}{ Normal } & Total & $\begin{array}{c}\boldsymbol{p} \text { - } \\
\text { value }\end{array}$ \\
\hline Dini & 0 & 0 & 0 & 0 & 0 & 0 & \\
Normal & 21 & 52.5 & 17 & 42.5 & 38 & 95 & \\
Lambat & 0 & 0 & 2 & 5 & 2 & 5 & & \\
\hline Total & 21 & 52.5 & 19 & 47.5 & 40 & 100 & \\
\hline
\end{tabular}

\section{Hubungan Antara Usia Menarche Ibu Dengan Usia Menarche Anak}

Hasil uji statistik menunjukkan bahwa nilai $p$-value dari hasil perhitungan tersebut adalah 0.134, yang mana hasil tersebut lebih besar dari 0.05 dapat dilihat pada tabel 10, hal tersebut menunjukan tidak adanya hubungan antara usia menarche ibu dengan usia menarche pada remaja putri usia 10 sampai 14 tahun di wilayah Perumahan Bumi Pertiwi 2.

Hal tersebut dapat terjadi karena perbedaan gaya hidup serta kemajuan teknologi yang dapat mempengaruhi perbedaan usia menarche yang menjadi lebih dini pada saat ini, karena pada jaman sekarang remaja putri lebih sering mengonsumsi fast food, snack, dan soft drink, konsumsi makanan tersebut secara berlebihan sebelum menarche akan menyebabkan peningkatan status gizi sehingga menyebabkan menarche dini (Nurrahmaton, 2013).

Menurut penelitian Ong et al dalam Herawati(2013) ketika kematangan seksual 
terjadi, seorang anak akan mengikuti waktu kejadian menarche ibunya. Usia menarche ibu dapat memberikan pengaruh terhadap percepatan pertumbuhan pada anak yang dapat mempengaruhi usia menarche anaknya, usia menarche pada ibu berkaitan dengan usia menarche putrinya namun hal tersebut tidak semata-mata hanya karena pengaruh dari genetik melainkan dari faktor lain seperti lingkungan keluarga.

Tabel 11. Hubungan Antara Status Gizi Dengan Usia Menarche

\begin{tabular}{|c|c|c|c|c|c|c|c|}
\hline \multirow{3}{*}{$\begin{array}{c}\text { Kategori } \\
\text { Status Gizi_ }\end{array}$} & \multicolumn{6}{|c|}{ Status Menarche } & \multirow{3}{*}{$\begin{array}{c}p- \\
\text { value }\end{array}$} \\
\hline & \multicolumn{2}{|c|}{ Dini } & \multicolumn{2}{|c|}{ Normal } & \multicolumn{2}{|c|}{ Total } & \\
\hline & $\mathbf{n}$ & $\%$ & $\mathbf{n}$ & $\%$ & $\mathbf{n}$ & $\%$ & \\
\hline Lebih & 11 & 27.5 & 3 & 7.5 & 14 & 35.0 & \\
\hline Normal & 8 & 20 & 11 & 27.5 & 19 & 47.5 & \\
\hline Kurang & 2 & 5 & 5 & 12.5 & 7 & 17.5 & ( \\
\hline Total & 21 & 52.5 & 19 & 47.5 & 40 & 100.0 & \\
\hline
\end{tabular}

\section{Hubungan Antara Status Gizi Dengan Usia}

\section{Menarche}

Hasil uji statistik menunjukkan bahwa terdapat hubungan antara status gizi dengan usia menarche pada remaja putri usia 10 sampai 14 tahun di wilayah Perumahan Bumi Pertiwi 2 (pvalue 0.379) pada tabel 11 .

Status gizi pada seorang remaja dapat mempengaruhi pertumbuhan fisik serta usia menarche. Seorang anak yang mengalami menarche dini akan memiliki status gizi yang lebih besar dibandingkan dengan mereka yang belum mengalami menarche di usia yang sama (Suryanda, 2017). Peningkatan status gizi berkaitan dengan penurunan usia menarche. Hal ini tersebut disebabkan terdapatnya Adypocytederived hormone Leptin yang berasal dari lemak pada tubuh yang diperkirakan sehingga dapat mempengaruhi masa awal pada pubertas. Peningkatan kadar leptin yang signifikan dalam darah dapat menyebabkan peningkatan kadar LH yang mana hal tersebut dapat mempengaruhi peningkatan estradiol dan awal dari kejadian menarche (Reswari dalam Sulung \& Yellisia, 2017).

Status gizi memiliki pengaruh terhadap tingkat kematangan seksual yang lebih dini pada kejadian menarche seseorang. Secara umum, seseorang yang mengalami kematangan seksual yang lebih dini akan memiliki status gizi yang lebih tinggi serta seseorang yang terlambat pada kematangan seksualnya akan memiliki IMT yang lebih kurang dengan usia yang sama (Derina dalam Putra, Pradnyani, et al., 2016).

\section{KESIMPULAN DAN SARAN}

Berdasarkan penelitian yang telah dilakukan, dapat diambil kesimpulan jika tidak terdapat hubungan antara asupan energi, lemak, karbohidrat, kalsium, serta usia menarche ibu dengan usia menarche pada remaja putri usia 1014 tahun di wilayah Perumahan Bumi Pertiwi 2, Kabupaten Bogor.

Lalu terdapat hubungan antara asupan protein dan status gizi dengan usia menarche pada remaja putri usia 10-14 tahun di wilayah Perumahan Bumi Pertiwi 2, Kabupaten Bogor.

\section{UCAPAN TERIMA KASIH}

Puji syukur penulis panjatkan kehadapan Allah SWT atas segala berkah dan karunia-Nya yang telah diberikan. Terima kasih kepada ibu Ikha Deviyanti Puspita, S.Gz, RD, MKM selaku pembimbing yang telah bersedia meluangkan waktu untuk memberikan arahan selama penyusunan penelitian. Terima kasih juga kepada 
responden dan seluruh pihak yang terlibat dalam penelitian ini.

\section{DAFTAR PUSTAKA}

Budi Mardiyanti 2012, Kejadian Menarche Pada Remaja Putri Di SMP Negeri 1 Tegalrejo Kabupaten Magelang 2012 Jurnal Kesehatan Masyarakat, Volume 1, Nomor 2, Tahun 2012, Halaman 605 $616,1$.

Chrisanti Fadhilla, 2018. Hubungan Konsumsi Susu Dengan Usia Menarche Pada Anak Usia 12-15 Tahun. Skripsi. Fakultas Kedokteran. Program Pendidikan Sarjana Kedokteran. Universitas Trisakti. Jakarta.

Fathin, N., Ardiaria, M., \& Fitranti, D 2017, Hubungan Asupan Lemak, Protein Dan Kalsium Dengan Kejadian Menarche Dini Pada Anak Usia 10-12 Tahun. Journal of Nutrition College, Volume 6, Nomor 3, Tahun 2017, Halaman Volume 6, Nomor 3, Tahun 2017, Halaman 249-256 Online, 6, 249-256.

Ganabathy, N. A., Widjajakusuma, A., \& Hidayat, D 2016, Age Pattern at Menarche as Results from a Puberty Survey. Althea Medical Journal, 3(4),640643.

Herawati, R 2013, Faktor-Faktor Yang Berhubungan Dengan Usia Menarche Pada Remaja Putri Di SMP Negeri 8 Tambusai Utara Tahun 2013. Jurnal Maternity and Neonatal, 1(3), 132.

Jahanfar, S., \& Walters, H 2019, Association of twins' sex discordance and age at menarche. Archives of Gynecology and Obstetrics, 0123456789.

Nurrahmaton 2013, Jurnal Midwifery Update ( MU ). Jurnal Midwifery Update, 8511, $39-49$.

Putra, I. G., et al 2016, Faktor-Faktor Yang Mempengaruhi Umur Menarche (Menstruasi Pertama) Pada Siswi Sekolah Dasar Di Kota Denpasar. BIMKMI Volume 4 No.1 | Januari-Juni 2016,

November 2017.

RISKESDAS 2013, Riset Kesehatan Dasar; Badan Penelitian dan Pengembangan
Kesehatan Kementerian Kesehatan RI

Tahun2010. Laporan Nasional 2010, 1446.

Rogers, I. S., Northstone, K., Dunger, D. B., Cooper, A. R., Ness, A. R., \& Emmett, P. M 2010, Diet throughout childhood and age at menarche in a contemporary cohort of British girls. 13(12), 2052-2063.

Sari, R., Udiyono, A., Saraswati, L., \& Ginandjar, P 2016, Gambaran Usia Menarche Dini Di Pada Anak Sekolah Dasar Di Daerah Urban. Jurnal Kesehatan Masyarakat (e-Journal), 4(4), 443-447.

Siwi, N. P., \& Paskarini, I 2018, Hubungan Asupan Karbohidrat, Lemak,Dan Protein Dengan Status Gizi (Studi Kasus pada Pekerja Wanita Penyadap Getah Karet di Perkebunan Kalijompo Jember ). The Indonesian Journal of Public Health, 2012(January), 1-12.

Sulung, N., \& Yellisia, M 2017, Factors Associated With Menarche At Seventh Grade. Volume 2.No.3 Tahun 2017 Jurnal Human Care, 2(3), 1-13.

Suryanda 2017, Hubungan status gizi dengan kejadian menarche siswi sdn 02 kota prabumulih. Jurnal Vokasi Kesehatan, $3(2), 1-5$.

Wulandari, P., Aini, N., \& Astuti, W. S 201, Faktor-Faktor Yang Berhubungan Dengan Kejadian Menarche Siswi Di SMPN 31 Semarang. Jurnal Keperawatan, P-ISSN 2086-3071 E-ISSN 2443-0900, 6, Nomor 2, 117-122.

Yu, E. J., Choe, S., Yun, J., \& Son, M 2020, Association of early menarche with adolescent health in the setting of rapidly decreasing age at menarche. Journal of Pediatric and Adolescent Gynecology. 